\title{
A complete citric acid cycle in assimilatory metabolism of Pelobacter acidigallici, a strictly anaerobic, fermenting bacterium
}

\author{
Andreas Brune and Bernhard Schink \\ Lehrstuhl Mikrobiwlogie I der Eberhard-Karls-Universität, Auf der Morgenstelle 28, D-7400 Tübingen, Federal Republic of Germany
}

Received March 28, 1990/Accepted May 21, 1990

\begin{abstract}
Pelobacter acidigallici is a strictly anaerobic bacterium that ferments trihydroxybenzenes to $3 \mathrm{~mol}$ acetate/mol substrate. The key intermediate linking the catabolic sequences to the formation of cell matter is acetyl-CoA. Since $P$. acidigallici is independent of further external electron donors, it must oxidize part of the acetyl-CoA to provide reducing equivalents for anabolism. In this study we demonstrate the presence of all enzymes necessary to operate a modified citric acid cycle, with activities sufficient to support growth. Unusual enzymes in the cycle are 2-oxoglutarate synthase and succinyl-CoA:acetoacetate CoA transferase. Anaplerotic reactions are catalyzed by pyruvate synthase, PEP synthetase and PEP carboxylase. No CO dehydrogenase, hydrogenase, or formate dehydrogenase activity could be detected. The phylogenetic implications of these findings with respect to the relatedness of $P$. acidigallici to gramnegative, sulfur-recucing bacteria by $16 S \mathrm{rRNA}$ cataloguing are discussed.
\end{abstract}

Key words: Trihydroxybenzenes -- Anabolism - Anaerobic citric acid cycle - Succinyl-CoA: acetoacetate CoA transferase - Phylogeny - Gram-negative bacteria

Pelobacter acidigallici is a strictly anaerobic, fermenting bacterium that grows with trihydroxybenzenes as carbon and energy source. Pyrogallol, phloroglucinol and their carboxylated derivatives are the only substrates; the trihydroxybenzenes are converted to stoichiometric amounts of acetate (Schink and Pfennig 1982). The reac-

Offrint requests to: $\Lambda$. Brume

Abbreviations: CoA, cocnzyme A; DCPIP, 2,4-dichlorophenolindophenol; DTNB, 5.5'-dithiobis(2-nitrobenzoic acid) "Ellman's rcagent"; DTT, 1,4-dithiothreitol; methyl viologen, 1,1'-dimethyl4,4'-bipyridinium dichloride; PEP, phosplioenolpyruvate; PMS, phenazin methosulfate; Tricine, $N$-[tris(hydroxymethyl)-methyl]glycine; T'ris, tris(hydroxymethyl)aminomethane tions involved in preparation of the aromatic substrates for ring cleavage via the novel phloroglucinol pathway have been studied previously (Samain et al. 1986; Brune and Schink 1990). The fate of the aliphatic ring-cleavage products in a pathway finally yielding three acetate per phloroglucinol by $\beta$-oxidation will be reported elsewhere (Brune and Schink, in preparation).

Siuce acetyl-CoA is the only degradation intermediate available for anabolism, $P$. acidigallici either has to use external electron donors to reduce acetyl-CoA and $\mathrm{CO}_{2}$ to the redox level of cell matter, or has to oxidize part of the acetyl CoA to meet this demand for rectucing equivalents in anabolism. While Eubacterium oxidoreducens depends on external formate or bydrogen for growth with trihydroxybenzenes (Krumbolz et al. 1987), $P$. acidigalici is independent of external electron donors other than trihydroxybenzenes (Schink and Pfennig 1982).

Not much attention has been paid to this general problem in anaerobic degradation. Only Malonomonas rubra, which thrives on decarboxylation of malonate to acetate and $\mathrm{CO}_{2}$, was reported to employ a complete citric acid cycle, most probably for acetate assimilation into cell matter (Dehning and Schink 1989). In this paper we present evidence on how $P$. acidigallicioxidizes acetyl$\mathrm{CoA}$ to $\mathrm{CO}_{2}$ via a complete citric acid cycle in order to generate reducing equivalents for conversion of acetyl$\mathrm{CoA}$ and $\mathrm{CO}_{2}$ to cell matter, and how acetyl-CoA is assimilated.

\section{Materials and methods}

Enxymes and co-enzymes were purchased from Boehringer (Mannheim, FRG), pyridine nucleotides and DTT from Biomol (Ilvesheim, FRG), CoA esters from Sigma (Deisenhofen. FRG). DTNB, DCPIP, PMS and methyl viologen were purchased from Fluka (Neu-Ulm, FRG). All other chemicals were of analytical grade or of the highest commercially available purity, also obtained from Fluka. $\mathrm{N}_{2}$ and $\mathrm{N}_{2} / \mathrm{CO}_{2}$ gas mixtures were more than $99.999 \%$ pure and were obtained from Messer Griesheim (Ludwigshafen, FR $G$ ). 


\section{Medium and growth conditions}

Pelobacter acidigallici strain MaGal2 (DSM 2377) was grown in bicarbonate-buffered, sulfidw-teduced saltwater mineral medium under a $\mathrm{N}_{2} / \mathrm{CO}_{2}(9: 1, \mathrm{v} / \mathrm{v}$ ) a tmosphere (Brune and Schink 1990). The substrate sodium gallate $(7.5 \mathrm{mM})$ was added to the medium from a filter-sterilized and anoxic stock solution. Cultures were incubated at $30^{\circ} \mathrm{C}$ in the dark.

\section{Preparation of cell suspensions and cell extracts}

Cells were harvested by centrifugation, washed once, and finally resuspended to yield a final cell density of about $2.5 \mathrm{mg}$ dry cell matter per $\mathrm{ml}$. Cell extracts were prepared by disruption in a French pressure cell; the crude extract was centrifuged to remove cell debris. All steps were performed under strict exclusion of air with $\mathrm{N}_{2}$ in the headspace of all vessels, and are described in more detail elsewhere (Brune and Schink 1990).

\section{Determination of enzyme activities}

Enzyme nomenclature and EC-numbers follow the suggestions of the International Union of Biochemistry (1984). Enzyme activities were determined spectrophotometrically in $1.5 \mathrm{ml}$ cuvettes $(d=$ $1 \mathrm{~cm}$ ), sealed with rubber stoppers and gassed with $\mathrm{N}_{2}$, at $25^{\circ} \mathrm{C}$. Additions were made to a final volume of $1 \mathrm{ml}$ from anoxic stock solutions with gas tight Unimetrics microliter syringes (MachereyNagel, Düren, FR(r), to prevent access of air. All activities are means of at least two independent assays of less than $10 \%$ variation with different cell extracts. A lincar relationship between activity and protein concentration was granted in all cases.

The assays contained cell extract with $10-100 \mu \mathrm{g}$ protein. Protein was quantitated by the micra-protein assay described by Bradford (1976), with bovine serum albumin as a standard. Buffers prereduced with DTT contained $1 \mathrm{mg} / 1$ resarario to verify a low redox potential during tho assay.

\section{Enzymes of the citric acid cycle}

Citrate synthase ( $\mathrm{EC}$ 4.1.3.7) was measured following the disappearance of acetyl-CoA $\left(\varepsilon_{23}=4.44 \mathrm{mM}^{-1} \mathrm{~cm}^{-1}\right)$ upon addition of oxaloacetate. The assay was modified after Bergmeyer et al. (1974) and contained Tris $/ \mathrm{HCl}, \mathrm{pH} 8.0,100 \mathrm{mM}$; Na-oxaloacetate, $0.2 \mathrm{mM}$; and $\mathrm{Li}_{3}$-acetyl-CoA, $0.15 \mathrm{mM}$. The assay mixture was incubated for 5 min in the absence of oxaloacetate to correct for background thioesterase activity.

Aconitase (EC 4.2.1.3) activity was determined by coupling citrate conversion to isocitrate with the isocitrate dehydrogenase reaction (Anfinsen 1955). The assay conditions were as with isocitrate dehydrogenase. only that isocitrate was replaced by $5 \mathrm{mM}$ Na-citrate as a substrate. The cell extract already contajned sufficient activities of isocitrate dehydrogenase (Table 1). The reaction was started with either citrate or $\mathrm{NADP}^{+}$.

Isocitrate dehydrogenase (EC 1.1.1.42) was assayed by monitoring the formation of NADPH from $\mathrm{NADP}^{-1}$ at $365 \mathrm{~nm}$ upon addition of isocitrate (Bernt and Bergmeyer 1974). The assay mixture contained Tris/HCl, $\mathrm{pH}$ 8.3, $100 \mathrm{mM} ; \mathrm{MgCl}_{2}, 10 \mathrm{mM} ; \mathrm{DTT}, 2.5 \mathrm{mM}$; $\mathrm{NADP}^{+}$or NAD ${ }^{+}, 2.5 \mathrm{mM}$; and DL-isocitrate, $1 \mathrm{mM}$.

2-Oxoglutarate synthase (EC 1.2.7.3) was measured according to Zeikus et al. (1977), following the reduction of methyl viologen with 2-oxoglutarate $\left(\varepsilon_{578}=9.7 \mathrm{mM}^{-1} \mathrm{~cm}^{-1}\right)$. The assay mixture contained Tricine/ $\mathrm{KOH}, \mathrm{pH} 8.5,100 \mathrm{mM} ; \mathrm{MgCl}_{2}, 10 \mathrm{mM} ; \mathrm{DTT}$,
$2.5 \mathrm{mM}$; K-2-oxoglutarate, $10 \mathrm{mM}$; methyl viologen, $10 \mathrm{mM}$; and $\mathrm{Li}_{3}-\mathrm{CoA}, 0.5 \mathrm{mM} .2-5 \mu \mathrm{l}$ of $0.1 \mathrm{mM} \mathrm{Na} \mathrm{S}_{2} \mathrm{O}_{4}$ were added to the cuvettes until the assay mixture was light blue. The reaction was started with either CoA or 2-oxoglutarate. A reduction of $2 \mu \mathrm{mol}$ of methyl viologen was defined as an oxidation of $1 \mu \mathrm{mol}$ of substrate, based on the stoichiometry of the reaction. 2-Oxoglutarate dehydrogenase complex was tested in a similar assay lacking methyl viologen and $\mathrm{Na}_{2} \mathrm{~S}_{2} \mathrm{O}_{4}$, but containing $1 \mathrm{mM} \mathrm{NADP}^{\prime}$ or $\mathrm{NAD}^{+}$ instead.

Succintl-CoA synthetase ( $\mathrm{EC}$ 6.2.1.4-5) activity was measured by coupling $C O A$ production to the chemical reaction of DTNB with the thiol group, forming a heterodisulfide. 5-Thio-2nitrobenzoic acid formation was recorded $\left(\delta_{412}=14.15 \mathrm{mM}^{-1} \mathrm{~cm}^{-1}\right)$ (Riddles et al. 1979). The assay contained Tris/ $\mathrm{HCl}, \mathrm{pH} 8.0,100 \mathrm{mM}$; $\mathrm{MgCl}_{2}, 2 \mathrm{mM}$; Na-succinyl-CoA, $0.5 \mathrm{mM}$; ADP or GDP, $2 \mathrm{mM}$; DTNB, $0.1 \mathrm{mM}$; and $\mathrm{NaH}_{2} \mathrm{PO}_{4}, 2 \mathrm{mM}$. DTT was omitted in the preparation of cell extracts because of the high background reaction.

Stacinyl-CaA : acetoacetate CoA transferase (EC 2.8.3.5) was measured by recording the disappearance of acetoacetyl-CoA upon addition of succinate (Lynen and Ochoa 1953) using $\varepsilon_{303}=$ $14.0 \mathrm{mM}^{-1} \mathrm{~cm}^{-1}$ determined for the acetaacetyl-CoA$/ \mathrm{Mg}^{2+} \mathrm{com}-$ plex (Stern 1956). The assay contained Tris/ $\mathrm{HCl}, \mathrm{pH} 8.3,100 \mathrm{mM}$; $\mathrm{MgCl}_{2}, 10 \mathrm{mM} ; \mathrm{Na}_{3}$-acetoacetyl-CoA, $0.1 \mathrm{mM}$; and Na-succinate, $10 \mathrm{mM}$. Enzyme activity was corrected for instability of acetoacetylCoA with cell extract prior to addition of succinate.

Succtinyl-CoA :acetate CoA transferase (EC 2.8.3.-) was determined following the disappearance of the thioester bond of succinyl-CoA $\left(\varepsilon_{233}=4.44 \mathrm{mM}^{-1} \mathrm{~cm}^{-1}\right)$ unon addition of acetate. Acetyl-CoA was removed from equilibtium by arsenolysis with phosphotransacetylase in arsenate buffer (Hilpert et al. 1984). The assay contained Na-arsenate buffer, pH 7.0, $10 \mathrm{mM}$; phosphotransacetylase, $20 \mathrm{U}$; Na-succinyl-CoA, $0.1 \mathrm{mM}$; and Na-acetate, $1 \mathrm{mM}$. Activily was corrected for thioesterase before addition of acetate.

Succinate dehydrogenctse (EC 1.3.99.1) was assayed with ferricyanide (Stams et al. 1984) or DCPIP as artificial electron acceptors. The assay contained Tris/ $\mathrm{HCl}, \mathrm{pH} 7.6,100 \mathrm{mM}$; Triton X-100, $0.01 \%$ $(w / v)$; PMS, $0.1 \mathrm{mM}$; Na-succinate, $20 \mathrm{mM}$; and $\mathrm{K}_{3} \mathrm{Fe}(\mathrm{CN})_{6}, \mathrm{mM}$ $\left(\varepsilon_{420}=0.9 \mathrm{mM}^{-1} \mathrm{~cm}^{-1}\right)$ or DCPIP, $0.1 \mathrm{mM}\left(\varepsilon_{522}=8.6 \mathrm{mM}^{-1}\right.$ $\left.\mathrm{cm}^{-1}\right)$.

Funarase (EC 4.2.1.2) activity was measured following fumarate disappearance $\left(\varepsilon_{250}=1.45 \mathrm{mM}^{-1} \mathrm{~cm}^{-1}\right)$ upon addition of cell extract (modified after Brandis-Heep et al. 1983). The assay contained Tris/ $\mathrm{HCl}, \mathrm{pH} 8.0,100 \mathrm{mM}$; and $\mathrm{Na}$-fumarate, $1 \mathrm{mM}$.

Malate dehydrogenase (EC 1.1.1.37) was monitored following oxidation of NADH or NADPH at $365 \mathrm{~nm}$ upon addition of oxaloacetatc (Stams et al. 1984). The assay contained Tris/ $\mathbf{H C l}$, $\mathrm{pH} 8.3,100 \mathrm{mM} ; \mathrm{MgCl}_{2}, 10 \mathrm{mM} ; \mathrm{DTT}, 2.5 \mathrm{mM} ; \mathrm{NADH}$ or NADPH, $0.25 \mathrm{mM}$; and Na-oxaloacetate, $0.3 \mathrm{mM}$.

\section{Enzymes of the $C O$ dehydrogenase pathway}

CO dehydrogenase (EC 1.2.99.2) was measured following the reduction of methyl viologen with $\mathrm{CO}\left(\varepsilon_{578}=9.7 \mathrm{mM}^{-1} \mathrm{~cm}^{-1}\right)$ in an assay modified after Diekert and Thauer (1978). The assay contrined potassium phosphate buffer, pII $7.2 \mathrm{mM}$; and methyl viologen, $5 \mathrm{mM}$. The $\mathrm{N}_{2}$-headspace of the cuvettes was flushed with $\mathrm{CO}$, and the assay mixture was prereduced as described for 2-oxoglutarate synthase.

Formate dehydrogenase (EC 1.2.1.2) was measured either with methyl viologen in an assay analogous to $C O$ dehydrogenase, except that $10 \mathrm{mM}$ formate substituted for $\mathrm{CO}$, or with pyridine nucleotides as electron acceptors (Spormann and Thauer 1988). 
Table 1. Fnzymes of the citric acid cycle found in cell extracts of Pelobacter acidigallici. For assay conditions see Materials and methods

\begin{tabular}{|c|c|}
\hline Enzyme & $\begin{array}{l}\text { Specific activily } \\
{\left[\text { mmol } \cdot \min ^{-1} \cdot \operatorname{mg}\right.} \\
\left.\text { protein }^{-1}\right]\end{array}$ \\
\hline 1 Citrate synthase ${ }^{b}$ & 1,120 \\
\hline 2 Aconitase & 152 \\
\hline 3 Isocitrate dehydrogenase $\left[\mathrm{NADP}^{+}\right]^{0}$ & 624 \\
\hline 42 -Oxoglutarate synthase ${ }^{\mathrm{L}}$ & 160 \\
\hline Succinate thiokinasc & $<10$ \\
\hline Succinyl-CoA: acetate CoA & \\
\hline $\begin{array}{l}\text { transferase } \\
5 \text { Succinyl-CoA: acetoacetale, }\end{array}$ & $<10$ \\
\hline CoA transferase & 2,860 \\
\hline 6 Succinate dehydrogenase ${ }^{e}$ & 320 \\
\hline 7 Fumarase & 4,000 \\
\hline 8 Malate dehydrogenase $\left[\mathrm{NAD}{ }^{\dagger}\right]^{f}$ & 5,600 \\
\hline \multicolumn{2}{|c|}{$\begin{array}{l}\text { Tested with methyl viologen as electron acceptor, no } \mathrm{NAD}^{+} \\
\text {dependent } 2 \text {-oxoglutarate dehydrogenase was detected } \\
\text { Tested with DCPIP in the presence of Triton } \mathrm{X}-100 \\
\text { f Activity with NADP }{ }^{+} \text {less than } 0.5 \%\end{array}$} \\
\hline
\end{tabular}

Fydrogenase (EC 1.18.99.1) assay was similar to that for $\mathrm{CO}$ dehydrogenase, only that $\mathrm{CO}$ was replaced by $\mathrm{H}_{2}$.

\section{Enzymes of anaplerotic or anabolic sequences}

Isocitrate lyase (EC 4.1.3.1) and malate symthase (EC 4.1.3.2) were determined as described by Dixon and Kornberg (1959).

Pyruvate synthase (FC 1.2.7.1) assay was similar to that for 2-oxoglutarate synthase. with $10 \mathrm{mM} \mathrm{Na-pyruvate} \mathrm{as} \mathrm{electron} \mathrm{do-}$ nor.

PEP synthetase (EC 2.7.9.2) was assayed according to methods $\mathrm{I}$, II and III of Eyzaguirre et al. (1982). Pyruvate: orthophosphate dikinase (EC 2.7.9.1) was tested by adding $10 \mathrm{mM}$ orthophosphate to the PEP synthetase assays.

Pyruvate carboxylase (EC 6.4.1.1) was assayed according to Seubert and Weicker (1969).

PEP-carboxylase (EC 4.1.1.31) was measured as bicarbonate-dependent oxaloacetale formation from PEP in a coupled test with malate dehydrogenase (Cánovas and Kornberg 1969). No addition of external malate dehydrogenasc was necessary because the cell extract contained sufficient activities (Table 1). The assay contained Tris/ HCl. $\mathrm{pH} 8.3,100 \mathrm{mM} ; \mathrm{MgCl}_{2} ; 10 \mathrm{mM} ; \mathrm{KHCO}_{3}, 10 \mathrm{mM}$; DTT; $2.5 \mathrm{mM} ; \mathrm{NADH}, 0.25 \mathrm{mM}$; acetyl-CoA, $0.5 \mathrm{mM}$; and PEP, $5 \mathrm{mM}$. $P E P$-carboxykinase (EC 4.1.1.32) was tosted by including $1 \mathrm{mM}$ ADP or GDP in the PEP carboxylase assay.

PEP-carboxytransphosphorylase (EC 4.1.1.38) was measured as described by Wood et al. (1969).

\section{Results}

\section{Entzymes of the citric acid cycle}

All enzymes necessary for operation of a citric acid cycle were present in the cell extract at sufficient activities
Table 2. Enzymes activities of further anabolic and anaplerotic reactions assayed in cell extracts of Pelobacter acidigallici. For assay conditions see Materials and methods

\begin{tabular}{|c|c|}
\hline Enrymc $^{a}$ & $\begin{array}{l}\text { Specific actiwity } \\
{\left[\text { [nmol } \min ^{-1} \cdot \mathbf{m g}\right.} \\
\left.\text { protein }^{-1}\right]\end{array}$ \\
\hline 9 Pyruvate synthasec & 136 \\
\hline 10 PEP synthetase & $<3$ \\
\hline Pyruvate:orthophosphate dikinase & $<3$ \\
\hline 11 PEP carboxylase & 32 \\
\hline Pyruvate carboxylase & $<3$ \\
\hline PEF carboxykituase & $<3$ \\
\hline PEP carboxytransphosphorylase & $<3$ \\
\hline Isocitrate lyase & $<1$ \\
\hline Malate synthase & $<2$ \\
\hline
\end{tabular}

"Number designation as in Fig. 1

h Activities $<3$ nmol min $^{-1} \cdot \mathrm{mg}$ protein $^{-1}$ were regarded as insignificant

c Tested with methyl viologen as electron acceptor

(Table 1). White most of the enzymatic activities tested showed no significant differences to a standard citric acid cycle $\left(\mathrm{NADP}^{+}\right.$-dependent isocitrate dehydrogenase, $\mathrm{NAD}^{+}$-dependent malate dehydrogenase), as normatly found in aerobic organisms (Thauer 1988), the following steps deviated from this pattern: i) No pyridine nucleotide-dependent 2-oxoglutarate dehydrogenase was detectable, but 2-oxoglutarate reduced methyl viologen upon addition of $\mathrm{COA}$, indicating the presence of a ferredoxin-dependent 2-oxoglutarate synthase. ii) Another unusual enzymatic activity catalyzed the conversion of succinyl-CoA to succinate. The free energy of the thioester bond was not used for phosphorylation of ADP or GDP, but was conserved by transferring the CoA moiety to acetoacetate, thus participating in acetoacetylCoA formation, an important step in the organism's catabolism (Brune and Schink, in preparation).

Succinate dehydrogenase coupled with artificial clectron acceptors such as DCPIP or ferricyanide in the presence of PMS as a redox mediator, and was stimulated by addition of Triton $X-100$. Specific activity was essentially the same with both electron acceptors. The natural cosubstrate of the enzyme is not known.

All activities were found to be sufficient to account for the turnover of acetate that has to be postulated from theoretical considerations. $P$. acidigallici growing on phloroglucinol at a growth rate $\mu$ of $0.25 \mathrm{~b}^{-1}$ must convert acetate to cell matter at a rate of $166 \mathrm{nmol} \cdot \mathrm{min}^{-1}$ . $\mathrm{mg}^{-1}$ protein. The reducing equivalents necessary for this reaction have to be produced by oxidizing acetate to $\mathrm{CO}_{2}$ at $10 \mathrm{nmol} \cdot \mathrm{min}^{-1} \cdot \mathrm{mg}^{-1}$ protein. These calculations are based on the equation: $17 \mathrm{CH}_{3} \mathrm{COOH} \rightarrow 8$ $\left\langle\mathrm{C}_{4} \mathrm{H}_{7} \mathrm{O}_{3}\right\rangle+2 \mathrm{CO}_{2}+6 \mathrm{H}_{2} \mathrm{O}$, and an experimentally determined correlation of $0.46 \mathrm{~g}$ protein per $\mathrm{g}$ of dry cell matter.

\section{Enzymes of further anabolic and anaplefotic sequences}

Formation of pyruvate from acetyl-CoA and $\mathrm{CO}_{2}$ was catalyzed by a methyl viologen-dependent pyruvate 
synthase. Methyl viologen could not be replaced by pyridine nucleotides, as already observed with 2-oxoglutarate synthase, indicating that reduced ferredoxin may be the natural reductant. Entry of pyruvate into gluconeogenesis could not be shown, but probably occurs via transformation to PEP, since PEP carboxylase was present at significant activity. This enzyme appeared to be strongly regulated because its activity decreased almost to zero if acetyl-CoA was omilted from the assay. No increase in activity was observed if ADP or GDP was added.

The reported activities (Table 2 ) again are in the order of magnitude expected by estimating the necessary anabolic flux from acetyl CoA to cell matter on the basis of the assumptions made above. No significant activities of methylmalonyl-CoA carboxy-transferase, pyruvate carboxylase, pyruvate-phosphate dikinase, or malic enzyme, all known to be involved in reactions between pyruvate, $\mathrm{PEP}$, and $\mathrm{C}_{4}$-dicarboxylic acids, could be detected. There was no evidence for the presence of the key enzymes of the glyoxylate cycle, isocitrate lyase and malate synthase.

\section{Enzymes of the CO dehydrogenase pathway}

No activity of the key enzymes of the CO dehydrogenase pathway, $\mathrm{CO}$ dehydrogenase and formate dehydrogenase, could be detected. There was also no hydrogenase activity.

\section{Discussion}

$P$. acidigalici possesses all enzymes necessary for the operation of a complete citric acid cycle (Table 1). This is highly unusual for a strictly fermenting bacterium, but is explained by the demand for redox equivalents to reduce acetyl-CoA and $\mathrm{CO}_{2}$ to cell matter in all bacteria forming only $\mathrm{C}_{2}$-intermediates in their energy metabolism. This problem is evident from theoretical considerations, but was demonstrated experimentally so far only in Malonomonas rubra (Dehning and Schink 1989).

The citric acid cycle of $P$. acidigallici (Fig. 1 ) is unusual compared to that of aerobic bacteria in using ferredoxin rather than pyridine nucleotides as the electron acceptor for oxidative decarboxylation of 2-0xoglutarate. This modification was found also in sulfateand sulfur-reducing bacteria oxidizing acetate via the citric acid cycle, in bacteria that operate a reversed citric acid cycle for $\mathrm{CO}_{2}$ fixation, and in some aerobic archaeobacteria (Thaner 1988). Reduced ferredoxin provides electrons of a redox potential negative cnough to drive the reductive carboxylation of acetyl-CoA to pyruvate by pyruvate synthase, which is also present in $P$. acidigallici.

Another unusual feature of this cycle is the conservation of the energy-rich thioester bond of succinyl- $\mathrm{CoA}$ by activation of acetoacetate in a $\mathrm{CoA}$ transferase reaction. This reaction was first reported to occur in human heart muscle tissue (Lynen and Ochoa 1953), but to our

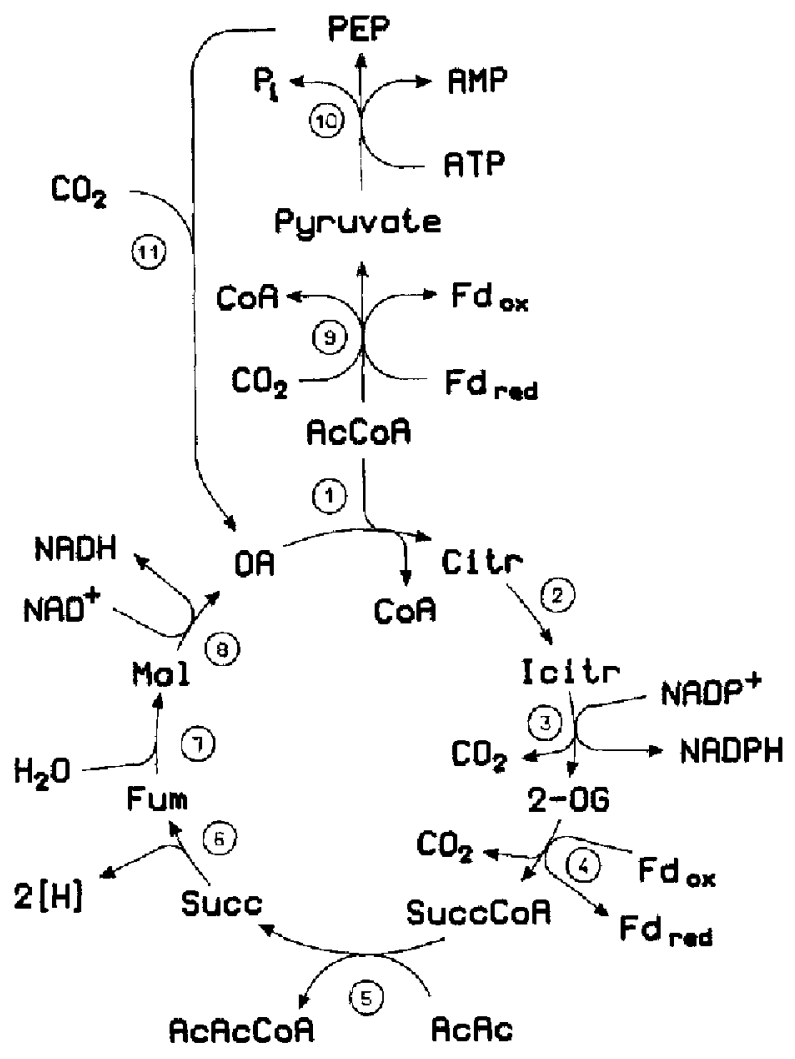

Fig. 1. Modified citric acid cycle proposed for Pelohacter acidirallici, serving as a source of reducing equivalents and melabolic pool for anabolism. Names and activities found in the cell extract for the enzymes indicated by numbers are given in Table 1 and 2. $A b$ breviations: Citr, citrate; Icitr, isocitsate; 2-OG, 2-oxoglutarate; Succ, succinate; Fum, fumarate; $M$ al malate; $O A$, oxaloacetate; $F d_{\text {ex/red }}$ oxidized/reduced ferredoxin; $A C A C$, acetoacetate. For further explanations refer to text

knowledge has not yet been found in bacteria. Transfer of the CoA moiety from succinyl-CoA to a fatty acid is typical of many strictly anacrobic bacteria (Thauer 1988). An explanation for the unusual substrate specificity of this enzyme may be its possible anaplerotic role in acetoacetate activation in energy metabolism (Brune and Schink, in preparation).

The physiological electron acceptor of succinate dehydrogenase is not known. It remains an open question whether the electrons from succinate $(+30 \mathrm{mV})$ have to be driven by reversed electron transport to a more negative acceptor as demonstrated in Desulfuromonas acetoxidans (Paulsen et al. 1986).

Entry of acetyl-CoA into the anabolic route proceeds via reductive carboxylation of acetyl-CoA to pyruvate by a probably ferredoxin-coupled pyruvate synthase. The anaplerotic reactions necessary to maintain an operating cycle concomitant with biosynthesis of cell matter proceed probably via PEP and its carboxylation to oxaloacetate, as reported for sulfur- and sulfate-reducing bacteria thriving on acetate and possessing pyruvate synthase (Brandis-Heep et al. 1983; Gebhardt et al. 1985). The activities found for PEP synthetase (Table 2) are insignificant, yet a direct transformation of pyruvate to PEP has 
to be postulated due to the findings that PEP carboxylase is present, and no enzymes of the glyoxylic acid bypass or of direct pyruvate carboxylation were detected. In addition, no carboxylation of pyruvate by methylmalonyl-CoA formed from succinyl-CoA could be verified, and no malic enzyme was detected.

All enzymes shown in Fig. 1, except PEP synthetase, are present in activities calculated to be more than sufficient to support growth at the given growth rate of the organism (see Results).

The alternative route employed by acetate-oxidizing organisms in terminal oxidation of acetate, the $\mathrm{CO}$ dehydrogenase pathway, can be excluded on the basis of a lack of key enzymes such as $\mathrm{CO}$ dehydrogenase or formate dehydrogenase in the crude extract of $P$. acidigallici. This agrees with the work of Schauder et al. (1986), who found that a valid test for the mode of acetate oxidation in sulfate-reducing bacteria is the presence or absence of these key enzymes of the respective pathways.

Studies on the phylogenetic position of $P$. acidigallici by $16 S$ rRNA cataloguing (Stackebrandt et al. 1989) showed a striking phylogenetic relatedness of this species to bacteria of the genus Desulfuromonas. This finding was surprising because the types of energy metabolism of these bacteria are entirely different. However, the presence of a complete citric acid cycle in $P$. acidigallici, and with that the capability of complete oxidation of acetyl moieties, is a metabolic trait shared with Desulfuromonas. It provides some support to the theory that fermentative metabolism in Pelobacter evolved secondarily from a common ancestor of both genera capable of electron transport phosphorylation. Even though $P$. acidigallici was so far not found to couple acetate oxidation to reduction of an exogenous electron acceptor, an evolution of its metabolism from acetate-oxidizing sulfur-reducing bacteria can now be visualized more easily. Further investigations on the presence of a citric acid cycle in other members of the genus Pelobacter are necessary to decide whether this trait offers some of the missing phenotypic data needed to explain the phylogenetic clustering of the two genera.

Acknowledgements. This work was partly supported by a fellowship of the Deutsche Gesellschaft für Chemisches Apparatewesen, Chemische Technik und Biotechnologie e.V. (DECIEMA), Frankfurt am Main, FRG, to A.B. We wish to thank Xiao Yn Wu for technical assistance and Karen $A$. Brune for reading the manuscript.

\section{References}

Anfinsen CB (1955) Aconitase from pig heart muscle. In: Colowick SP, Kaplan NO (eds) Methods in enzymology, vol I. Academic Press, New York, pp 695-698

Bergmeyer HU, Gawehn K, Grabl M (1974) Enzyme als biochemische Reagentien. In: Bergmeyer $H U$ (ed) Methoden der enzymatischen Analyse, vol I, 3rd edn. Verlag Chemie, Weinheim, pp 454-558

Bernt E, Bergmeyer HU (1974) Isocitrat-Dehydrogenase. UV-Test. In: Bergmeycr HU (cd) Methoden der enzymatischen Analyse, vol I, 3rd edn. Verlag Chemie, Weinheim, pp 660-663
Bradford MM (1976) A rapid and sensitive method for the quantitation of microgram quantities of protein utilizing the principle of protein-dye binding. Anal Biochem 72:248-254

Brandis-Heep A, Gebhardt NA, Thauer RK, Widdel F, Pfennig N (1983) Anaerobic acetate oxidation to $\mathrm{CO}_{2}$ by Desulfobacter postgatei. 1. Demonstration of all enzymes required for the operation of the citric acid cycle. Arch Microbiol 136:222229

Brune A, Schink B (1990) Pyrogallol-to-phloroglucinol conversion and other hydroxyl-transfer reactions catalyzed by cell extracts of Pelobacter acidigallici. J Bacteriol 172:1070-1076

Cánovas JL, Kornberg HL (1969) Phosphoenolpyruvate carboxylase from Echerichia coli. In: Lowenstein JM (ed) Methods in enzymology, vol XIII. Academic Press, New York London, pp $288-292$

Dehning I, Schink B (1989) Malonomonas rubra gen. now sp. nov., a microaero tolerant anaerobic bacterium growing by decarboxylation of malonate. Arch Microbiol 151:427-433

Diekert GB, Thauer RK (1978) Carbon monoxide oxidation by Clostridium thermoaceticum and Clostridium formicoaceticum. $\mathrm{J}$ Bacteriol 136:597-606

Dixon GH, Kornberg HL (1959) Assay methods for key enzymes of the glyoxylate cycle. Biochem J $72: 3 \mathrm{p}$

Eyzaguirre J, Jansen K, Fuchs G (1982) Phosphoenolpyruvate synthetase in Methanobacterium thermoautotrophicum. Arch Microbiol 132:67-74

Gebhardt NA, Thauer RK, Linder D, Kaulfers PM, Pfennig N (1985) Mechanism of acetate oxidation to $\mathrm{CO}_{3}$ with elemental sulfur in Desulfuromonas acetoxidans. Arch Microbiol 141: $392-398$

Hilpert W, Schink B, Dimroth P (1984) Life by a new decarboxylation-dependent encrgy conservation mecharism with $\mathrm{Na}^{+}$ as coupling ion. EMBO J 3:1665-1670

International Union of Biochemistry (1984) Enzyme nomenclature 1984. Academic Press, Orlando, Florida

Krumholz LR, Crawford RL, Hemling ME, Bryant MP (1987) Metabolism of gallate and phloroglucinol in Eubacteriam oxidoreducens via 3-hydroxy-5-oxohexanoate. J Bacteriol $169: 1886-1890$

Lymen F, Ochon S (1953) Enzymes of fatty acid metabolism. Biochim Biophys Acta 12:299-314

Paulsen J, Kröger $\Lambda$, Thauer RK (1986) ATP-driven succinate oxidation in the catabolism of Destufuromonas acetoxidans. Arch Microbiol 144:78-83

Riddles PW, Blakeley RL, Zerner B (1979) Elman's reagent: 5,5dithiobis(2-nitrobenzoic acid) - a reexamination. Anal Biochem 94:75-81

Samain F, Albagnac G, Dubourguier HC (1986) Initial steps of catabolism of trilhydroxybenzenes in Pelobacter acidigallict. Arch Microbiol 144:242-244

Schauder R, Eikmanns B. Thauer RK, Widdel F, Fuchs G (1986) Acctate uxidation to $\mathrm{CO}_{2}$ in anaerobic bacteria via a novel pathway not involving reactions of the citric acid cycle. Arch Microbiol 145:162-172

Schink B, Pfennig N (1982) Fermentation of trihydroxybenzenes by Pelobacter acidigallici gen. nov. sp. nov., a new strictly anaerobic, non-sporeforming bacterium. Arch Microbiol 133:195-201

Seubert W. Weicker H (1969) Pyruvatc carboxylase from Pseudomonas. In: Lowenstein JM (ed) Methods in enzymology, vol XUI. Academic Press, New York London, pp 258262

Spormann AM, Thauer RK (1988) Anacrobic acetate oxidation to $\mathrm{CO}_{2}$ be Desulfotomaculum acetoxidans. Demonstration of enzymes required for the operation of an oxidative acelyl-CoAi carbon monoxide dehydrogenase pathway. Arch Microbiol $150: 374-380$

Stackebrandt E, Wehmeyer U, Schink B (1989) The phylogenctic status of Pelobacter acidigallici, Pelobacter venetianus, and Pelobacter carbinolicts. System Appl Microbiol 11:257260 
Stams A.IM, K temer DR, Nicolay K, Weenk GH, Hansen TA (1984) Pathway of propionate formation in Desulfobulbus propionicus. Arch Microbiol 139:167 - 173

Stern JR (1956) Optical properties of acetoacetyl-S-coenzyme A and its metal chelates. J Biol Chem 221:33-44

Thauer RK (1988) Citric-acid cycle, 50 years on. Modifications and an alternative pathway in anacrobic bactcria. Fur J Biochem $176: 497-508$
Wood HG, Davis JJ, Willard IM (1969) Phosphoenolpyruvate carboxytransphosphorylase from Propionibacterium shermanii. In: Lowenstein JM (ed) Methods in enzymology, vol XIII. Academic Press, New York London, pp 297-309

Zeikus JG, Fuchs G, Kenealy W, Thaner RK (1977) Oxidoreductases involved in cell carbon synthesis of Methanobacterium themoautotrophicum. J Bacteriol 132:604-613 